\title{
MINERAL RESOURCE POTENTIAL OF THE PINEY CREEK WILDERNESS, STONE AND BARRY COUNTIES, MISSOURI
}

\author{
By
}

\author{
Walden P. Pratt and Ralph L. Erickson, U.S. Geological Survey, \\ Kenneth C. Thomson, Southwest Missouri State University, \\ and Clarence EHlis, U.S. Bureau of Mines
}

\section{Studies Related to Wilderness}

\begin{abstract}
Under the provisions of the Wilderness Act (Public Law 88-577, September 3, 1964) and the Joint Conference Report on Senate Bill 4, 88th Congress, the U.S. Geological Survey and the U.S. Bureau of Mines have been conducting mineral surveys of wilderness and primitive areas. Areas officially designated as "wilderness," "wild," or "canoe" when the act was passed were incorporated into the National Wilderness Preservation Syste $m$, and some of them are presently being studied. The act provided that areas under consideration for wilderness designation should be studied for suitability for incorporation into the Wilderness Syste $\mathrm{m}$. The $\mathrm{m}$ ineral surveys constitute one aspect of the suitability studies. The act directs that the results of such surveys are to be made available to the public and be submitted to the President and the Congress. This report discusses the results of a mineral survey of the Piney Creek Wilderness, Mark Twain National Forest, Stone and Barry Counties, Mo. The area was established as a wilderness by Public Law $94-557$, October 19, 1976.
\end{abstract}

\section{MINERAL RESOURCE POTENTIAL SU M MARY STATEMENT}

There is no evidence of significant metallic-mineral deposits in the rock units that are exposed at the surface in the wilderness, but there may be some potential for mineral deposits of two different types at depths from $400 \mathrm{ft}(120 \mathrm{~m})$ to more than $2,100 \mathrm{ft}(640 \mathrm{~m})$ below the surface. Analyses of rock sa $\mathrm{m}$ ples from a drill hole $15 \mathrm{mi}(24 \mathrm{~km})$ south of the area showed anomalous a mounts of several metals in the Derby-Doerun (usage of the Missouri Geological Survey), Potosi, and Eminence Dolomites, which suggests that these units as well as the subsurface ordovician carbonate units may have a potential for zinc-lead mineralization in the wilderness. Also, a high-amplitude magnetic anomaly along the northwest side of the wilderness suggests a potential for a small to moderate-sized magnetite (iron ore) deposit in the Precambrian basement rocks at a depth of at least $2,100 \mathrm{ft}$ $(640 \mathrm{~m})$ below the surface, probably at least partly outside the boundary of the wilderness. In both cases the significance of the potential cannot be evaluated without deep drilling. In the case of the possible magnetite deposit, drilling should be preceded by a detailed magnetic survey to delineate the anomaly mor clearly. The wilderness has little potential for resources of industrial minerals because they are readily available elsewhere in the region, and no known potential for energy resources.

\section{INT RO D U CTION}

The U.S. Geological Survey and the U.S. Bureau of Mines made a geologic and mineral survey to assess the mineral resource potential of the Piney Creek Wilderness, southwest Missouri, in 1978-80. The wilderness covers 8,432 acres $(3,412$ hectares) of the Mark Twain National Forest in Stone and Barry Counties (fig. 1).

The wilderness is near the western edge of the Sale $m$ Plateau region of the $\mathrm{Ozark}$ uplift and contains timbered ridges, remnants of a maturely dissected upland surface, separated by the valley of Piney Creek and its tributaries. Exposed rocks are nearly flat lying limestones and dolomites of Mississippian and Ordovician ages. These are underlain by about $1,700 \mathrm{ft}$ $(520 \mathrm{~m})$ of mostly carbonate sedimentary rocks of ordovician and Cambrian ages, which rest on Preca $\mathrm{m}$ brian base $\mathrm{m}$ ent igneous rocks.

There is no known record of mineral production, development, or prospecting in the wilderness.

\section{GEOLOGY}

The Piney Creek Wilderness is on the southwest flank of the 0 zark uplift. The rock units exposed are limestones of Mississippian age and dolomites of 0rdovician age, which dip very gently northeast (fig. 2). These units are underlain by some $1,700 \mathrm{ft}(520 \mathrm{~m})$ of dolomites and minor sandstones of Ordovician and Cambrian ages, which rest upon basement igneous rocks of Precambrian age. The geologic structure is simple, and there are no known faults within the wilderness.

\section{GEOC HE MIST R Y}

Stream-sediment samples and pannedconcentrate samples from eleven drainages tributary to Piney Creek (fig. 2) were collected and analyzed for 30 elements by semiquantitative spectrographic methods. The analyses show a remarkably uniform content for each metal and indicate that anomalous 


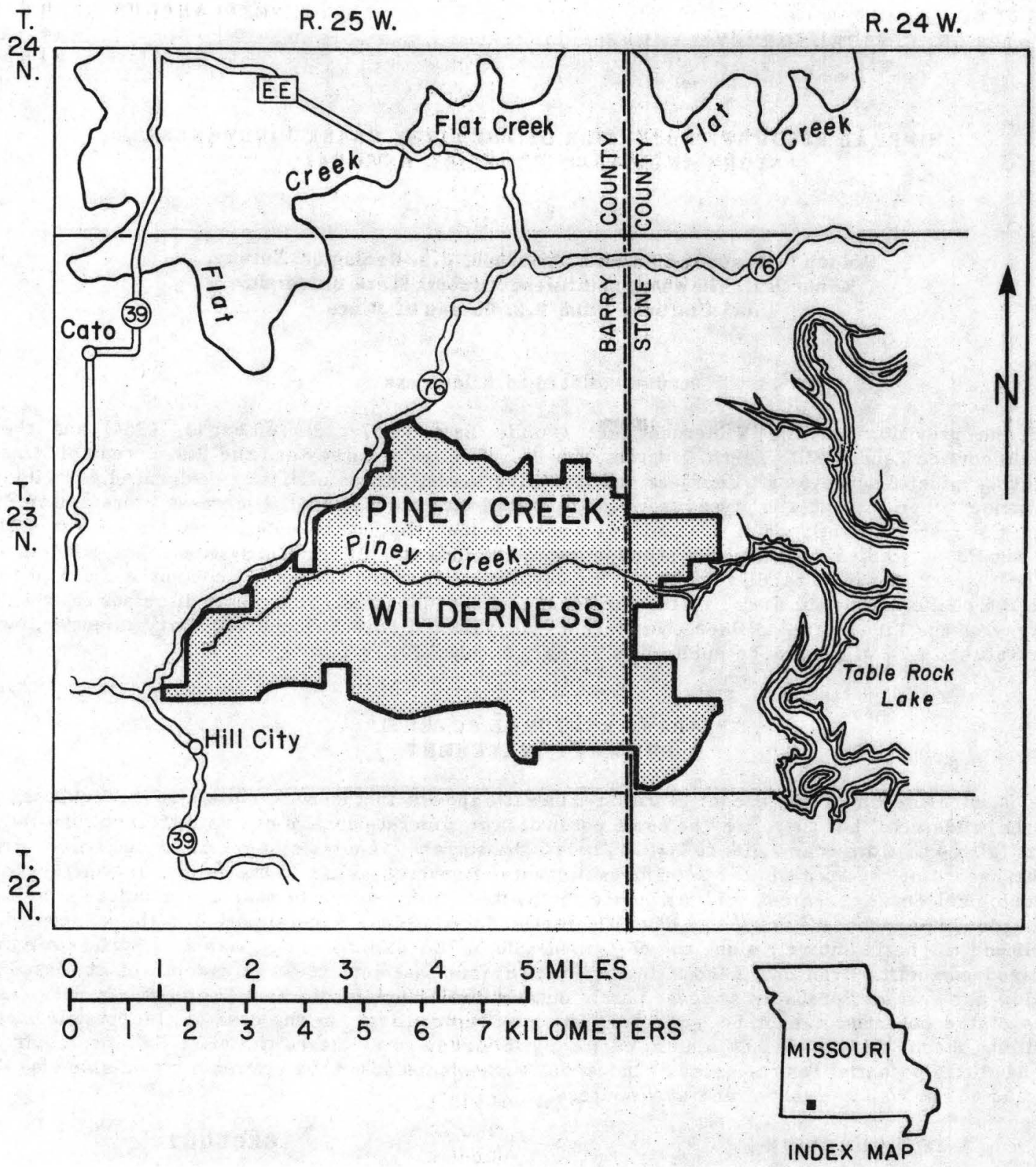

Figure 1.--Index map showing the Piney Creek Wilderness. 
concentrations of metals probably are not present in the surface formations of the area. Enhanced metal values detected in the panned-concentrate samples reside in limonitic iron oxide derived from the ubiquitous, sparsely disseminated pyrite in the surface rocks of the area.

\section{GEOPH YSICS}

The magnetic $\mathrm{map}$ of Missouri (Missouri Geological Survey, 1943b) shows a crescent-shaped high-amplitude positive magnetic anomaly along the northwest side of the wilderness. The high a mplitude and apparently steep gradient of this ano maly indicate a source at or near the surface of the Precambrian basement, which is about $2,100 \mathrm{ft}(640 \mathrm{~m})$ below the upland surface. However, the anomaly is based on magnetic readings at $2-\mathrm{mi}(3.2-\mathrm{km})$ intervals along highways, and a more detailed magnetic survey of the area is needed to delineate the anomaly accurately before further inferences can be made as to its significance.

On the gravimetric map of Missouri (Missouri Geological Survey, 1943a), the wilderness is on the southeast limb of a gentle, oval-shaped northwesttrending positive gravity anomaly. The source of this feature must be at a deep level in the Precambrian basement and cannot be identified on the basis of available geologic data. Detailed gravity trends are not resolved within the wilderness because no gravity stations exist within several miles of its border.

\section{MININ G DISTRICTS AN D MINERALIZ ATION}

There is no mining activity within the wilderness at present, no production has been reported, no mineralization is discernible on the surface, and there is no evidence of prospecting in the wilderness. The wilderness is several miles southeast of the Tri-State zinclead mining district as broadly defined (Heyl and others, 1966), and is about $12 \mathrm{mi}(20 \mathrm{~km})$ from the McDowell deposit, the nearest known deposit of basemetal sulfides (McKnight and others, 1962). The McDowell and other small mines in Barry County have produced 507 tons (460 tonnes) of lead and 1,021 tons (926 tonnes) of zinc. A small prospect named the Wild Cat mine was opened on a show of galena in the Cotter Dolomite in the SW1/4 N W1/4 sec. 29 , T. 23 N., R. 24 W., about $0.5 \mathrm{mi}(0.8 \mathrm{~km})$ east of the wilderness. Only sand, gravel, and limestone have been produced near the wilderness; some quarries are within $2 \mathrm{mi}(3.2 \mathrm{~km})$ of the wilderness. Except for 100 acres ( 40.4 hectares) in the $\mathrm{NW} 1 / 4 \mathrm{sec} .28$, T. $23 \mathrm{~N} ., \mathrm{R} .25 \mathrm{~W}$., all mineral rights in the wilderness have been held by the U.S. Government since 1975. No prospecting permits are on record.

\section{ASSESSMENT OF MINERAL RESOURCE POTENTIAL}

Although the wilderness is near the Tri-State zinc-lead district, there is no evidence of Tri-State type (stratabound) mineral deposits within the wilderness. As noted in the section on Geochemistry, the stream-sediment samples and panned-concentrate samples collected within the wilderness, representing all the principal drainages, indicate that anomalous concentrations of metals probably are not present in the surface formations of the area. No mineralized rocks were found during traverses of the area. Analyses of galena and altered dolomite from a small prospect just east of the wilderness showed strikingly low amounts of commonly associated trace metals, suggesting that an extensive mineralized syste $m$ is not present in the area.

The foregoing observations apply to the 0rdovician and Mississippian form ations that are exposed at the surface, which represent the lowermost of the units known to be mineralized in the Tri-State district. In the Southeast Missouri district, some $150 \mathrm{mi}(240 \mathrm{~km})$ northeast of the wilderness, mineral deposits of the same type are concentrated in the Bonneterre Formation of Cambrian age, and theoretically, the Bonneterre and other carbonate units that underlie the Cotter Dolomite in the wilderness could have some potential for zinc-lead mineralization. Analyses of insoluble residues from subsurface Cambrian formations, from drill holes along a traverse that passes about $15 \mathrm{mi}(24 \mathrm{~km})$ south of the wilderness, showed anomalous amounts of several metals in the Derby-Doerun, Potosi, and Eminence Dolomites at depths of about 1,500-1,850 ft (450$560 \mathrm{~m}$ ) below the surface (Erickson and others, 1981). This indicates that metal-bearing fluids passed through these formations over a large area, and in the light of recent studies in the Rolla $1^{\circ} \times 2^{\circ}$ quadrangle (Erickson and others, 1978, 1979), suggests that these Cambrian units, as well as the subsurface Ordovician carbonate units, may have a potential for base-metal mineralization in the wilderness. The significance of this potential, however, cannot be evaluated without deep drilling to provide information on the lithology and anomalous metal content of these formations within or close to the wilderness.

In the Southeast Missouri mining district, several major magnetic iron-ore deposits of past or potential importance occur in Precambrian rhyolitic volcanic rocks, and each of these major deposits is $\mathrm{m}$ arked by a positive magnetic anomaly of at least several hundred gam mas (Kisvarsanyi, 1981). The high-amplitude magnetic anomaly along the northwest side of the wilderness, together with the inferred presence of rhyolitic volcanic rocks in the Precambrian basement, suggest a potential for a magnetite deposit in this area, but because of the lack of definition of the anomaly as well as the absence of specific data on the lithology of the basement in this area, the only inference possible is that a potential exists. This potential cannot be confirmed or ruled out without a detailed magnetic survey and physical (drilling) evidence of the basement lithology. If the anomaly is indeed caused by a magnetite deposit, the deposit is probably at a depth of at least $2,100 \mathrm{ft}(640 \mathrm{~m})$ below the upland surface, and is probably at least partly outside the boundary of the wilderness.

The wilderness has little potential for economic resources of industrial minerals that are not readily available elsewhere in the region. Dolomite and limestone occur within the wilderness, but abundant supplies are available in nearby areas. Sand, gravel, and limestone have been produced near the wilderness, and at the time of this investigation, quarries about $2 \mathrm{mi}(3.2 \mathrm{~km})$ south of the area were producing crushed stone from the Cotter Dolomite. 


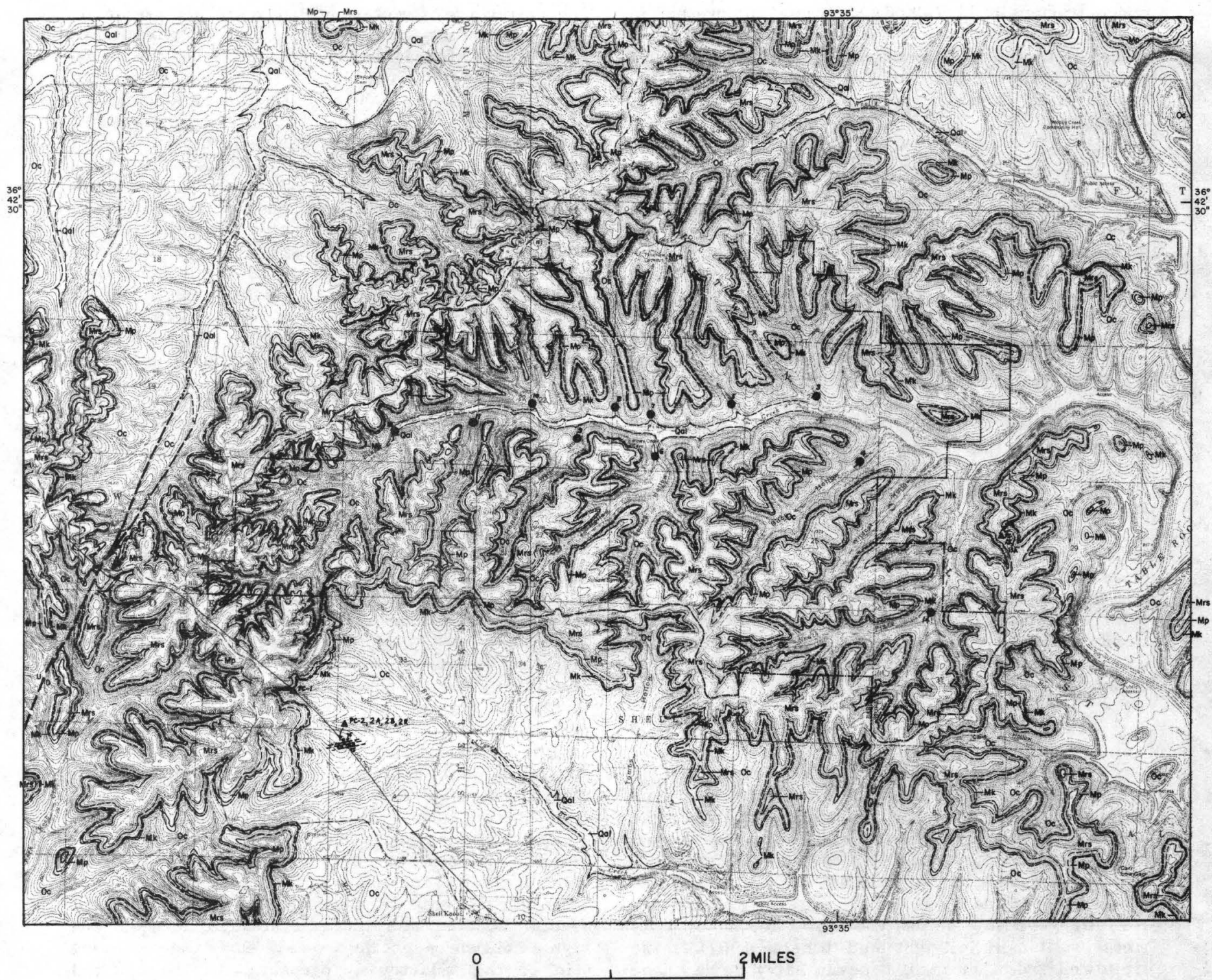

CORRELATION OF MAP UNITS

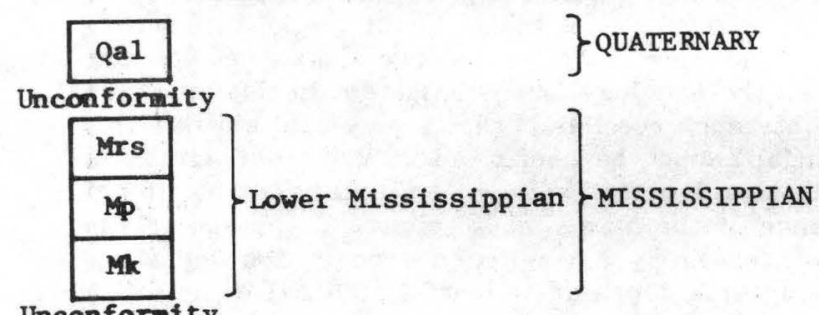

Unconformity

ac \}Lwer Ordovician \}orDOVICIAN

EXPLANATION OF MAP SYMBOLS APPROXIMATE BOUNDARY OF WILDERNESS

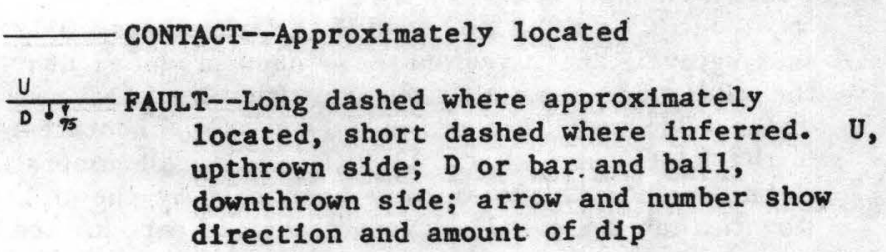

- stream-SEdiment AND PanNED-CONCENTRATE SAMPLE LOCALITY

$\triangle^{\text {PC-1 }}$ BEDROCK SAMPLE LOCALITY

Figure 2.--Geologic map of the Piney Creek Wilderness. 


\section{DESCRIPTION OF MAP UNITS}

REEDS SPRING FORMATION (LOWER MISSISSIPPIAN-OSAGEAN)--Gray to 11ght-brown, thin- to medium-bedded, micritic to finely crystalline limestone. Includes 40-70 percent dark-gray to brown chert as irregular nodules and thin discontinuous beds. Weathers easily to a chert-strewn surface. Outcrops are rare in the Piney Creek area. Where formation is exposed, chert appears in weathered rellef on ragged outcrops. Thickness about 80-100 ft (about 25-30 m)

PIERSON FORMATION (LOWER MISSISSIPPIAN-OSAGEAN)--Gray to 1ight-brown, thin- to medium-bedded, fine- to mediumcrystalline limestone, with as much as 50 percent gray to dark-gray chert occurring as nodules and beds predominantly in upper part. Generally separated from the Reeds Spring Formation by a thin shale layer. Formation name follows usage of Missouri Geological Survey. Thickness about $50 \mathrm{ft}$ ( $15 \mathrm{~m}$ )

Mk

NORTHVIEW AND COMPTON FORMATIONS, UNDIVIDED (LOWER MISSISSIPPIAN--KINDERHOOKIAN)

Northview Formation--Red to gray limestone and green to 11ght-blue-green shale; outcrops rare. Thickness about 1-3 ft (about $0.3-0.9 \mathrm{~m}$ )

Compton Formation--Light-gray to 11ghtbrown, medium- to thick-bedded, fine- to medium-crystalline limestone with lightgreen shale partings. Weathers to a characteristic wavy surface. Outcrops falrly common in roadcuts and on steep hillsides. Commonly forms a bench which is easily observed on aerial photographs. Thickness $15-20 \mathrm{ft}(5-6 \mathrm{~m})$

Oc

COTTER DOLOMITE (LOWER ORDOVICIAN--CANADIAN)-Light-brown to gray, medium- to thickbedded, fine-grained dolomite and minor chert. Weathers light or dark gray. Outcrops common along steep hill slopes and in valley floors. Thickness about $200 \mathrm{ft}(60 \mathrm{~m})$; base not exposed 
There is no known potential for energy resources in the wilderness. The 0zark uplift is considered to be geologically unfavorable for oil and gas occurrence (Anderson and Wells, 1967). All the known coal-bearing strata in Missouri are of Pennsylvanian age; rocks as young as Pennsylvanian are not present in or near the wilderness, and in general southwestern Missouri is considered unfavorable for coal resources (Robertson, 1971). No evidence of potential for radioactive-mineral deposits or for geothermal-energy sources was found in the wilderness.

\section{REFE REN CES}

Anderson, K. H., and Wells, J. S., 1967, 0il and Gas, in Mineral and water resources of Missouri: Missouri Division of Geological Survey and Water Resources [Report], 2d series, v. 43, p. 243-250.

Erickson, R. L., Mosier, E. L., Odland, S. K., and Erickson, M. S., 1981, A favorable belt for possible mineral discovery in subsurface $\mathrm{Cam}$ brian rocks in southern Missouri: Economic Geology, v. 76, no. 4, p. 921-933.

Erickson, R. L., Mosier, E. L., and Viets, J. G., 1978 , Generalized geologic and sum mary geochemical maps of the Rolla $1^{\circ} \times 2^{\circ}$ quadrangle, Missouri: U.S. Geological Survey Miscellaneous Field Studies Map MF-1004-A, scale $1: 250,000$.
Erickson, R. L., Mosier, E. L., Viets, J. G., and King, S. C., 1979, Generalized geologic and geochemical maps of the Cambrian Bonneterre Formation, Rolla $1^{\circ} \times 2^{\circ}$ quadrangle, Missouri: U.S. Geological Survey Miscellaneous Field Studies Map M F-1004-B, scale $1: 250,000$.

Heyl, A. V., Delevaux, M. H., Zartman, R. E., and Brock, M. R., 1966, Isotopic study of galenas from the Upper Mississippi Valley, the mlinois-Kentucky, and some Appalachian Valley mineral districts: Economic Geology, v. 61 , no. 5, p. 933-961.

Kisvarsanyl, E. B., 1981, Kiruna-type ironapatite(-copper) deposits, in Pratt, W. P., ed., Metallic mineral resource potential of the Rolla $1^{\circ} \times 2^{\circ}$ quadrangle, Missouri, as appraised in Septe $m$ ber 1980: U.S. Geological Survey OpenFile Report 81-518, p. 26-34.

McKnight, E. T., Newman, W. L., and Heyl, A. V., Jr., 1962, Zinc in the United States, exclusive of Alaska and Hawail: U.S. Geological Survey Mineral Investigations Resource Map M R-19, scale $1: 3,168,000$.

Missouri Geological Survey, 1943a, Gravimetric map of Missouri: Missouri Geological Survey, scale $1: 500,000$.

1943b, Magnetic map of Missouri: Missouri Geological Survey, scale 1:500,000.

Robertson, C. E., 1971, Evaluation of Missouri's coal resources: Missouri Geological Survey and Water Resources Report of Investigations 48, 92 p. 